\title{
CONDITIONS AND FACTORS DETERMINING THE DEMAND FOR SPORTS TOURISM IN THE WORLD
}

\author{
Oleksandr KOLOTUKHA
}

\author{
Vinnichenko Kirovograd State Pedagogical University, Ukraine \\ okolotuh@ukr.net
}

\begin{abstract}
Through the influence on the conditions and factors it is possible to affect the dynamic processes occurring in the territorial entities. Such entity is sports tourism which constitutes a kind of active recreation and tourism activity carried out in the natural environment and involves passing of tourist sport routes and overcoming various obstacles.

The external environment in terms of sports tourism can be presented in the form of two constituents: natural and social. Natural geosystem serves as a base substrate system of sports tourism and is represented by the natural surrounding and ecological macroenvironment. General geosystem is represented by social, political, economic, cultural macroenvironments.

Social and economic conditions of forming the demand for sports tourism in the world include an assessment of geographical location, transportation availability, and degree of provision of tourism with industries necessary for its service, degree of infrastructure development and completeness of package of services. Among the social conditions of tourism development it is necessary to emphasis on the increase of leisure time duration for population which in combination with rising standards of life means increasing the number of potential tourists interested in active forms of tourism.

Based on research of Russian geographer L. Y. Mazhar, we identified factors forming the demand for sports tourism which can be grouped into two types: no localizing factors, that is tourist and recreational needs, organizational, managerial, economic, material and domestic, social, psychological, health care, environmental, innovation factors, staff assistance factors; localizing factors - geotorical, geopolitical, natural and recreational, historical and cultural, infrastructural, recreation and activity.

The combined effect of determined conditions and factors form a stable growing demand for sports tourism in the world.
\end{abstract}

Key words: conditions, factors, causes, sports tourism, the concept of social space

UDC: 911.3

\section{УМОВИ ТА ФАКТОРИ ФОРМУВАННЯ ПОПИТУ НА СПОРТИВНИЙ ТУРИЗМ У СВІТІ}

\author{
Олександр колотУХА \\ Кіровоградський державний педагогічний університет імені В. Винниченка \\ okolotuh@ukr.net
}

\begin{abstract}
Анотація: Через вплив на умови і фактори можна впливати на динамічні процеси, що протікають в територіальних утвореннях. Таким утворенням $€$ спортивний туризм - вид активної рекреаційно-туристської діяльності, яка здійснюється в природному середовищі, і полягає у проходженні туристських спортивних маршрутів з подоланням різноманітних перешкод.

Зовнішнє середовище щодо спортивного туризму можна представити у вигляді двох складових: природної та суспільної. Природна геосистема виступає як базис, субстрат системи спортивного туризму і представлена природним та екологічним оточуючими макросередовищами. Суспільна геосистема представлена соціальним, політичним, економічним, культурним оточуючими макросередовищами.

Соціально-економічні умови формування попиту на спортивний туризм у світі передбачають оцінку географічного положення, транспортної доступності, ступеня забезпеченості туризму необхідними для його обслуговування галузями, ступеня розвитку інфраструктури та повноти комплексу послуг. Серед соціальних умов розвитку туризму слід виокремити збільшення тривалості вільного часу населення, що у поєднанні зі зростанням рівня життя населення означає збільшення кількості потенційних туристів, зацікавлених у активних видах туризму.

Спираючись на дослідження російського географа Л.Ю. Мажар, нами визначені фактори формування попиту на спортивний туризм, які можна об'єднати в два типи: нелокалізуючі фактори - туристсько-рекреаційні потреби, організаційноуправлінські, економічні, матеріально-побутові, соціально-психологічні, медико-санітарні, екологічні, інноваційні фактори, фактори кадрового забезпечення; локалізуючі фактори - геоторіальні, геополітичні, природно-рекреаційні, історикокультурні, інфраструктурні, рекреаційно-діяльнісні.
\end{abstract}

Сукупна дія визначених умов та факторів формують стійкий зростаючий попит на спортивний туризм в світі.

Ключові слова: умови, фактори, чинники, спортивний туризм, концепція соціального простору

\section{удк: 911.3}

Вступ. Постановка проблеми. Умови та фактори визначають формування і розвиток всіх географічних об'єктів і процесів. Їх дослідження $€$ важливим елементом географічного аналізу не

(C) О. Колотуха т1льки 3 теоретично1 точки зору, але 13 практично1. Це пов'язано з тим, що через вплив на умови і фактори можна впливати на динамічні процеси, що протікають в територіальних утвореннях. Те ж можна сказати i щодо розвитку рекреаційно-туристської діяльності: «Щоб цей процес носив цілеспрямований характер 
i був керований, необхідна наукова оцінка умов i факторів, що обумовлюють розвиток і розміщення рекреаційної галузі» [5, с. 74]. Разом 3 тим, в даний час немає достатньої ясності щодо дефініцій «умови» і «фактори».

Одним 3 таких рекреаційних територіальних утворень виступає спортивний туризм - вид активної рекреаційно-туристської діяльності, яка здійснюється в незайманому або слабозміненому природному середовищі, i полягає у проходженні туристських спортивних маршрутів 3 подоланням різноманітних перешкод природного середовища (перевалів, вершин, порогів, каньйонів, печер, боліт тощо)різнимизасобамипересуванняізвикористанням спеціальних технічних прийомів і спорядження [1, с. 12]. До категорії спортивного туризму ми відносимо активний туризм, пригодницький туризм, екстремальний туризм та види активної спортивної рекреації (альпінізм, скелелазіння, льодолазіння, яхтинг, дайвінг та ін.).

У геопросторовому вимірі спортивний туризм стає всебільш вагомим сегментом світової туристської галузі, впевнено займаючи за показниками розвитку третє місце після відпочинково-розважального та пізнавального туризму. Тому для прогнозування розвитку спортивного туризму в світі актуальним $\epsilon$ дослідження умов та факторів, що формують попит на цей сегмент світового туризму.

Виклад основного матеріалу. Всі явища, що зумовлюють або породжують інші явища, називаються причиною. Поняття «причина» дуже об'ємне. Воно включає як явища всередині об'єкта (внутрішні причини), так і явища поза ним (зовнішні причини). У випадку об'єкту нашого дослідження - спортивного туризму - всі явища, що мають на нього вплив, доцільно розглядати у взаєминах досліджуваного об'єкту та його середовища. В цьому разі, внутрішні причини будуть пов'язані 3 властивостями самого спортивного туризму, а зовнішні причини - 3 властивостями середовища, в якому він здійснюється. Ймовірно, що внутрішні причини мають велику силу впливу на процеси, що протікаютьв цьомугеопросторовому явищі,іїх можна кваліфікувати як «фактори». Це підтверджується й універсальним визначенням поняття «фактор»це «причина, рушійна сила будь-якого процесу, що визначає його характер або його окремі риси» [7, c. 596]. Тоді, умови - це зовнішні чинники, що мають вплив на процеси та явища, але не визначають їх характер і властивості.

Системний аналіз туристсько-спортивної діяльності як важливої та соціально значимої складової рекреаційної діяльності дав нам право стверджувати, що спортивний туризм є специфічною територіальною рекреаційною системою територіальною системою спортивного туризму [2, c. 126]. Спортивний туризм як специфічна система постає перш за все у відносинах 3 оточуючими макросередовищами: соціальним, політичним, економічним, культурним, природним та екологічним. Зовнішній світ активно впливає на туристськоспортивну діяльність, в одних випадках відкриваючи перед нею широкі можливості, в інших - загрожуючи новими небезпеками. Щоб вижити та зберегти ефективність, система вимушена пристосовуватися до умов - змін у зовнішньому оточенні.

Незважаючи на гетерогенний i досить складний за своїм елементарним складом характер, спортивний туризм відноситься до категорії соціально-економічних систем 3 високим рівнем організації (самоорганізації). Більш високим рівнем організації володіють лише інтегральні територіальні суспільні системи (ТСС), в рамках яких додатково до територіальних соціальноекономічних систем розглядаються соціальні, політичні, економічні структури, органи державного та регіонального управління, громадські організації тощо. Отже, ТСС 3 iï «додатковими»елементами і специфічними властивостями виступає зовнішнім середовищем по відношенню до системи спортивного туризму.

Зовнішне середовище щодо спортивного туризму досить умовно можна представити у вигляді двох складових: природної та суспільної. Природна геосистема в усьому iï різноманітті як базис, субстрат системи спортивного туризму, представлена природним та екологічним оточуючими макросередовищами. Очевидно вона буде визначальним середовищем для розвитку туристсько-спортивної системи, так само як і для всієї інтегральної суспільної геосистеми будьякого ієрархічного рівня в цілому. Суспільна геосистема, в свою чергу, представлена соціальним, економічним, політичним, культурним оточуючими макросередовищами.

Схематичні побудови дозволяють структурувати середовище і представити умови у вигляді певного ïx набору 3 необхідним для дослідження спортивного туризму ступенем деталізації. Наприклад, в рамках природної геосистеми складаються певні природні умови, в тому числі кліматичні, орографічні, гідрологічні, ландшафтні та інші. Важливо підкреслити, що умови формуються за рахунок властивостей об'єктів, що входять в природну геосистему. Причому ряд природних об'єктів 3 того ж числа може входити до системи спортивного туризму за рахунок властивостей, затребуваних в туристсько-спортивній діяльності, зокрема: естетичні властивості ландшафту, орографічні характеристики місцевості, наявність різноманітних природних перешкод тощо. У такому випадку ці властивості природних об'єктів дозволяють нам включати їх у категорію спортивних рекреаційнотуристських ресурсів, а отже, i в територіальну систему спортивного туризму у якості об'єктів, що входять до природно-рекреаційної підсистеми.

Для організації туристсько-спортивної діяльності можуть використовуватись такі ресурси природного походження:

- ландшафтні (мальовничі та унікальні
ландшафти);
- геологічні (геологічні утворення, геологічні пам'ятки природи, розрізи, гірські породи, мінерали); 
- геоморфологічні (різноманітні форми рельєфу - гірські вершини, перевали, вулканічні масиви, печери, яри, балки тощо);

- кліматичні (мають опосередкований вплив, однак від них залежить кількість сонячних днів та показники сонячного сяйва, кількість опадів, висота снігового покриву, сила вітрів тощо);

- гідрологічні (річки, водні перешкоди, водойми, джерела мінеральних та термальних вод тощо);

- грунтово-рослинні (грунти різної прохідності, червонокнижні рослини, унікальні фітоценози, ендемічні та реліктові рослини);

- зоологічні (червонокнижні та ендемічні тварини).

Оцінка природних умов, методологічні основи якої були розроблені групою російських вчених під керівництвом В.С. Преображенського, є одним 3 найбільш вивчених аспектів даної проблематики [6]. Автори запропонували виділяти три аспекти цієї оцінки: психологічний (емоційний вплив ландшафту), фізіологічний (ступінь комфортності природних умов для організму туриста) та технологічний (оцінка можливостей інженерного освоєння території).

Природні та екологічні умови, визначають можливості сталого розвитку туризму, його екологічно-спрямованих видів (екологічного туризму, спортивного туризму), попит на які зростає, реструктуризуючи туристський ринок. Все більшою мірою вибір конкретного туристсько-спортивного продукту обумовлюється екологізацією людської свідомості і тоді стан довкілля та природоохоронна політика обумовлюють можливості здійснення туристсько-спортивної діяльності. Дія зазначених умов також по-різному проявляється на світовому, регіональному та національному рівнях, але спільним для них $\epsilon$ «територіальна експансія» екологічно спрямованої туристсько-спортивної діяльності, коли попит на види та форми активного туризму, засновані на максимальному використанні природних ресурсів задля задоволення попиту спілкування з природою або випробування власних сил та вмінь в екстремальних природних умовах, стимулює розвиток туризму «вшир», залучення до «туристського обігу» нових територій, до того слабо або зовсім не задіяних в туризмі. Такими територіями виступають малозаселені, найчастіше економічно слаборозвинені, але сприятливі для розвитку спортивного туризму місцевості і в цьому випадку туризм стимулює їх економічний розвиток.

Позитивним $\epsilon$ також подальший розвиток туризму в національних парках та інших природних резерватах. Але екологізація туристського попиту несе в собі й негативні впливи. Переважна більшість природних рекреаційних ресурсів світу достатньо давно експлуатується (узбережжя морів та океанів, бальнеологічні ресурси, гірські території тощо) i їх стан викликає занепокоєння не тільки окремих країн, а й всієї світової громадськості, оскільки загальне зростання туристського попиту, підсилене модою та кон'юнктурою, спричинює перевантаження туристсько-рекреаційних районів та окремих центрів і веде до їх деградації. Якщо додати сюди суб'єктивні чинники підвищеного шуму, забруднення побутовими відходами, «перенаселеність» туристами, що впливають на конкретний попит, то можна стверджувати, що тотальна екологізація туризму є процесом об'єктивним.

Оцінка соціально-економічних умов $є$ більш трудомістким завданням з вельми високим ступенем невизначеності, оскільки саме соціально-економічне середовище дуже неоднорідне i динамічне. Ряд пропозицій з вивчення соціально-економічних умов передбачають оцінку географічного положення, транспортної доступності, ступеня забезпеченості туризму необхідними для його обслуговування галузями господарства та соціальної сфери 3 урахуванням спеціалізації регіону, ступеня розвитку інфраструктури та повноти вже сформованого комплексу послуг.

Однак при будь-якому підході до вивчення умов формування системи спортивного туризму особливе значення приділяється географічним умовам, i, перш за все, географічному положенню. В даний час досить поширеною $є$ думка, що географічне положення необхідно розглядати як фактор формування туристсько-рекреаційних систем.

Щодо вивчення умов формування системи спортивного туризму важливо підкреслити, що власне «географічне положення» - це категорія інтегральна. При необхідності їі можна деталізувати і виділити окремі складові, кожна з яких має свої особливості. Наприклад, при характеристиці фізикогеографічного положення акценти робляться на розташуванні об'єкта в системі координат, положенні щодо кліматичних поясів i областей, природних зон, важливих природних об'єктів (океанів, морів, гір, пустель, великих річок, озер тощо). Економікогеографічне положення включає в себе різні його види:політико-географічне,транспортно-географічне тощо.

У контексті географічного положення особливою категорією з розряду умов формування системи спортивного туризму виступає туристськогеографічне положення, яке відображає положення досліджуваного об'єкта по відношенню до розташованих поза ним інших об'єктів туристськорекреаційного призначення (туристські центри та дестинації, об'єкти природної і культурної спадщини, туристська інфраструктура тощо).

Соціально-економічні умови формування попиту на спортивний туризм у світі слід розглядати на трьох рівнях - загальносвітовому, регіональному та національному.

До умов загальносвітового рівня відносяться: глобалізація суспільного життя та інтернаціоналізація багатьох сфер соціальноекономічної діяльності;

- стан світового туристського ринку та його складових, регульований низкою міжнародних угод та діяльністю міжнародних урядових і неурядових організацій;

- поступ науково-технічного прогресу.

На регіональному рівні дія цих умов 
визначається:

нерівномірністю соціально-економічного розвитку країн, що впливає як на пропозицію, так і на споживання специфічних туристсько-спортивних послуг;

- інтегративними процесами різного порядку, що дає можливість, наприклад, шляхом введення єдиної валюти (євро) та спрощення візового режиму (Шенгенська угода) стимулювати внутрішньо регіональний туризм;

- функціонуванням фінансової сфери, що знаходить свій відбиток у коливанні курсів валют та відповідному коливанні попиту на туристськоспортивні послуги;

- політичною стабільністю, оскільки конфлікти на довгий строк вилучають цілі регіони з туристського обміну (наприклад, Балкани в 90-ті роки XX ст., Крим з 2014 року).

На національному рівні дія соціальноекономічних умов найбільш яскраво відбивається у державній політиці стимулювання активного туризму, яка проявляється в правовому забезпеченні, соціальній сфері, економічній, в т.ч. податковій політиці, у сфері зайнятості.

Серед умов загальносвітового рівня особливе місце займає всеохоплюючий вплив науковотехнічного прогресу як на формування потреб у подорожуванні, так і на їх забезпечення. Вплив на формування потреби в туризмі здійснюється одразу в кількох напрямках:

- зміна характеру праці в бік ㄲï наукоємності, що потребує кваліфікованої робочої сили і тим самим стимулює зростання рівня освіти і відповідних змін в потребі змістовного проведення дозвілля, що впливає на структуру використання вільного часу;

- скорочення робочого часу за рахунок інтенсифікації праці, механізації та автоматизації виробництва і відповідне зростання бюджету вільного часу;

- інтенсифікація праці збільшує психологічні навантаження на людину, також стимулюючи потребу у змістовному відпочинку, зміні вражень;

- зміна оточення в бік превалювання штучного середовища посилює психологічні навантаження i стимулює потребу спілкування 3 незайманою природою;

- подальша інформатизація суспільства, розвиток новітніх засобів комунікацій, що можна вважати не лише технічним, а й культурним стимулом розвитку туризму.

Отже, серед соціальних умов розвитку туризму необхідно виокремити збільшення тривалості вільного часу населення, що у поєднанні зі зростанням рівня життя населення означає збільшення кількості потенційних туристів, зацікавленість у нових видах відпочинку, в першу чергу активних видах туризму та рекреації. Зростає роль розумової праці, посилюються виробнича i побутова напруженість. Все це призводить до фізичної і психологічної перевтоми людей, що вимагає застосування додаткових заходів по відновленню працездатності. Досягненню цієї мети багато в чому сприяє активний туризм та рекреація. До соціальних чинників розвитку туристськоспортивної діяльності ми відносимо також такі як підвищення рівня освіти, культури, естетичних потреб населення. Соціологічні дослідження останніх років свідчать про те, що існує пряма залежність між рівнем освіти людей і їх схильністю до активних подорожей. Це пояснюється тим, що особи з більш високим рівнем освіти і культури здатні раціональніше розподіляти свій вільний час, використовувати його для активного пізнання навколишнього середовища, ознайомлення 3 історією, традиціями, побутом населення певних територій тощо.

Завдяки спортивному туризму людина знаходиться в тісному зв'язку 3 природним середовищем, яке вона формує, при цьому простір стає продуктом соціальним. Тому, на нашу думку, туристський простір слід розглядати не тільки як фізичний простір, але і як соціальний простір. Він формується на основі тенденції зростаючого інтересу людей до природи і дбайливого ставлення до навколишнього середовища, заснованого на концепціях сталого, збалансованого розвитку туризму. Існування цього інтересу безпосередньо пов'язано з двома світовими тенденціями в розвитку туризму - глобалізацією i екологізацією. Поряд 3 глобальним поширенням високотехнологічних туристських послуг відбувається і диверсифікація попиту, яка виражається в затребуваності альтернативного туризму - екологічного, активного, спортивного тощо.

Концепцію соціального простору висунув відомий французький соціальний теоретик і філософ А. Лефевр. Це - концепція виробництва простору. Основний лейтмотив у неї наступний: соціальний простір - соціальний продукт. На думку А. Лефевра, соціальний простір «сам по собі» апріорно ніколи не існує, він невпинно, скрізь і завжди, «денно і нощно» виробляється і відтворюється. У своїй роботі «Виробництво простору» французький філософ відстоює положення, що практична діяльність суб'єкта в просторі становить тривимірну систему - просторова практика, уявлення простору i просторове уявлення [3].

Застосовуючи концепцію А. Лефевра, можна стверджувати, що туристська діяльність виступає просторовою практикою, яка формується, а потім здійснюється на основі уявлення простору різноманітної інформації про туристську дестинацію 3 iï природними об'єктами, перешкодами та атракціями. Після здійснення туристської подорожі формується просторове уявлення про цю туристську дестинацію. Це $є$ рушійною силою, яка рухає туристів на відвідування нових туристських районів, на підкорення нових маршрутів, досягнення нових вершин. Вивчення проблематики соціального простору крізь призму теорії А. Лефевра дало новий дослідницький імпульс подальшій розробці дискурсивної теорії соціального простору. Саме дана теорія може стати одним 3 перспективних напрямків у вивченні соціальної реальності.

Серед опосередкованих впливів найбільш 
суттєвим є загальний поступ науково-технічного прогресу, завдяки якому відбулося «стиснення» простору і практично будь-яка точка Земної кулі стала не лише доступною, але й подорож туди $є$ комфортною, безпечною та необтяжливою. Постійно зростає якість туристського спорядження, що підвищує комфортність проживання в польових умовах, удосконалюються інші складові туристськоспортивного продукту, навіть для виживання в екстремальних умовах. Таким чином, не тільки формується потреба в дозвіллі, а й зростають можливості його змістовного проведення. Тобто, науково-технічний прогрес забезпечує загальний цивілізаційний поступ, проявляючись в змінах моделей соціально-економічного розвитку суспільства i, відповідно, створює умови для розвитку такого окремого явища, як спортивний туризм.

Група умов, пов'язаних із населенням, $\epsilon$ основою формування попиту, його обсягу та структури, темпів диверсифікації та реструктуризації, соціальної та територіальної диференціації, характеру споживання та інших ознак. Населення характеризується рядом процесів: демографічних (демографічні показники), міграційних (характер та напрямки міграціі), урбанізаційних (питома вага міського населення в загальній структурі та його розподіл по містах різної величини), агломераційних (характер та форми розселення), етнокультурних (саморозвиток та трансформація традиційної культури), релігійних (релігійність населення, конфесійна мозаїчність тощо), які впливають на формування якості та стилю життя, в структурі якого різною мірою наявний туризм. Їх дія також по-різному проявляється на різних ієрархічних рівнях.

Загальносвітовий урбанізаційний процес знаходить свій прояв не тільки в збільшенні частки міського населення та в агломеруванні розселення, а й у поширенні міського способу життя і відповідного йому стилю життя 3 його споживчими стандартами. Жителі міст, особливо великих мегаполісів, $\epsilon$ головними споживачами туристсько-спортивного продукту.

На регіональному рівні особливо помітні демографічні відміни та міграційні особливості, пов'язані 3 природним та механічним рухом населення.

На національному рівні на перший план виступають такі характеристики, як характер розселення, етно-релігійний склад населення, а також чисельність трудових ресурсів, рівень та структура зайнятості. В групі чинників, що характеризують населення, крім пов'язаних із формуванням загального попиту, слід обов'язково розглядати змінні чинники, що впливають на коливання та структуру попиту і серед них:

- соціальна мобільність (готовність до «зміни місця»), пов'язана зі станом здоров'я, який обмежує переміщення, вибір терміну та місця, виду чи форми туризму або транспортних засобів для подорожування;
- рівень культури, в залежності від якого або збуджується інтелектуальний інтерес, або проявляється етноцентризм (прихильність до національних особливостей життя i відповідна неспроможність сприйняти інший стиль життя 3 його традиціями, пристосуватися до нових умов);

- $з$ сімейними обставинами;

- 3 відношенням до певних незручностей туристсько-спортивної подорожі та до ризику під час мандрівки.

Сукупна дія розглянутих попередньо груп чинників формує рівень та умови життя населення, впливає на формування потреб та забезпечує платоспроможний попит на послуги туризму, визначає його структуру та міру іiі диверсифікації, характер споживання та його територіальну диференціацію відповідно до конкретних умов соціально-економічного середовища, яке саме й визначає доступність спортивного туризму для якомога більшої частини населення i забезпечує його гуманістичну спрямованість.

Як окрему умову розвитку спортивного туризму i, відповідно, стимулюючим чи лімітуючим чинником попиту для конкретного ринку слід розглядати безпеку подорожування. Безпека визначається як природними, так i соціальноекономічними та політичними умовами. Природні катастрофи, зокрема стихійні лиха (особливо слабо передбачувані), такі як землетруси, виверження вулканів, повені, урагани, цунамі, сходження снігових лавин, селі тощо роблять розвиток спортивного туризму в певному регіоні ризикованим, хоча й приваблюють частину екстремальних туристів. Зростання впливу людської діяльності на довкілля спричинило ризик антропогенних катастроф (зсуви, провали, селі). Техногенні катастрофи, як наприклад, катастрофа на Чорнобильській AEC у 1986 році, практично назавжди виводять 3 туристсько-спортивного використання значні території. Від рівня соціальноекономічного розвитку залежить спроможність держави створити та підтримувати в безпечному стані інфраструктуру (шляхи сполучення, мости, тунелі), забезпечити безпеку руху транспорту та транспортних засобів (впровадження та дотримання нормативів безпеки), безпеку в туризмі визначає й політична ситуація (можливість виникнення збройних конфліктів та тероризм).

Сукупна дія зазначених зовнішніх чинників (умов) формує загальний попит на подорожування, який переростає в запит до ринку туристських послуг відповідно до платоспроможності населення, яка є похідною від рівня соціально-економічного розвитку і є характеристикою рівня і якості життя населення.

Аналіз розвитку спортивного туризму дає підстави стверджувати, що на сучасному етапі розвитку суспільства сформований стереотип життя, обов'язковим елементом якого стало активне подорожування як форма дозвілля. Відповідно до цього варіюється та еволюціонує мотивація подорожування. Специфічна мотивація до спортивних туристських походів як сукупність 
обставин та причин, що спонукають людину до конкретної зміни місця, до випробувань, лежить в основі всієї туристсько-спортивної діяльності.

Отже, туристсько-спортивний процес $\epsilon$ результатом взаємодії сторін суспільних відносин, які формуються під впливом об'єктивних постійно та поліаспектно діючих умов (особливості природного середовища, екологічного стану, демографічних, міграційних, етнокультурних, релігійних, урбанізаційних, агломераційних, політичних процесів, систем господарювання) i чинників (геодемографічних, соціокультурних) та суб'єктивних психолого-поведінкових ознак особистості, сукупний вплив яких фіксується певним життєвим стандартом, зреалізованим у споживчих моделях та соціальній поведінці населення:

1) модель «вільного часу» передбачає стійкість туристської мотивації;

2) модель життєзабезпечення - періодичність туристської мотивації;

3) модель виживання - туристська мотивація відсутня.

Таким чином, умови створюють природну, соціальну та економічну обстановку, в якій відбувається зародження i розвиток системи спортивного туризму. Основною ж рушійною силою, яка формує територіальну структуру всієї системи i визначає ii властивості, є внутрішні причини фактори, які $\epsilon$ рушійною силою для формування структури спортивного туризму та відповідних його властивостей, що набирають чинності усередині системи.

Критичний аналіз усіх запропонованих підходів до вивчення факторів, що формують рекреаційнотуристський попит, виконав російський географ B.C. Преображенський, зазначивши, що головною проблемою всіх існуючих підходів $\epsilon$ недостатня увага до потреб людей i перебільшення ролі рекреаційних ресурсів у формуванні територіальних рекреаційних систем. «Кожна система формується, перш за все, як відповідь на соціальний запит, як засіб задоволення неоднорідних у функціональному i територіальному відношенні потреб, оскільки відпочиваючі обирають ресурси, виходячи, насамперед, зі своїх потреб» [8, 38]. Він же запропонував угруповання факторів, підрозділивши їх на:

1) фактори, які породжують потребу у рекреаційно-туристській діяльності;

2) фактори, які реалізують цю потребу, при цьому зазначив, що і ті й інші можуть бути територіально нелокалізуючими і такими, що локалізується, дія яких чітко просторово диференційовано [8, с. 38].

Подальший розвиток проблема вивчення факторів, що формують рекреаційно-туристський попит, отримала в роботах М.С.Мироненка та I. T. Твердохлєбова, які стосовно міжнародного туризму розглянули чотири групи постійно діючих факторів:

1) група соціально-економічних факторів;

2) фактори, пов'язані з рекреаційними ресурсами природного та антропогенного походження;
3) інфраструктурні фактори;

4) фактор географічного положення країни або регіону $[5$, с. 150$]$.

Російський географ Л. Ю. Мажар, досліджуючи територіальні туристсько-рекреаційні системи, визначила 14 груп факторів та чинників їх формування: геоторіальні; туристсько-рекреаційні потреби людини; економічні; геополітичні; організаційно-управлінські; інфраструктурні; матеріально-побутові; соціально-психологічні; демографічні; екологічні; медико-санітарні; рекреаційно-діяльнісні; інноваційні; фактори кадрового забезпечення. Оригінальною $є$ думка про те, що з плином часу змінюється роль факторів, i це дозволяє виявляти домінуючі фактори на певних етапах розвитку туристсько-рекреаційної діяльності [4, с. 11-12]. Пропонований автором варіант відрізняється високим ступенем деталізації, що дозволяє максимально врахувати різноманітні внутрішні чинники, що впливають на розвиток туризму в сучасних умовах.

Взявши за основу визначені Л. Ю. Мажар групи факторів та чинників формування туристського попиту, запропонуємо власне бачення на фактори формування попиту на спортивний туризм у світі (табл. 1).

Фактори формування попиту на спортивний туризм можна об'єднати в два типи:

1. нелокалізуючі фактори - туристськорекреаційні потреби, економічні, організаційноуправлінські, матеріально-побутові, соціальнопсихологічні, медико-санітарні, екологічні, інноваційні фактори, фактори кадрового забезпечення;

2. локалізуючі фактори - геоторіальні, геополітичні, природно-рекреаційні, історикокультурні, інфраструктурні, рекреаційно-діяльнісні.

Поділ груп факторів на типи є досить умовним, оскільки навіть нелокалізуючі фактори мають просторову складову, виражену в тій чи іншій мірі. Таким чином, за своєю суттю всі фактори впливають на територіальний аспект формування та розвитку спортивного туризму.

Для географічного аналізу чинників формування системи спортивного туризму особливу значимість мають геоторіальні фактори, пов'язані 3 конкретним місцем розташування районів проведення туристсько-спортивних подорожей, просторовим розташуванням туристсько-спортивних об'єктів, положенням об'єктів в систем географічних координат, топологічними характеристиками території, можливістю прокладання туристськоспортивних маршрутів. Раніше ми дійшли висновку, що власне «географічне положення» характеризує вплив інших об'єктів, що знаходяться поза досліджуваної системи, на даний об'єкт. Цей зовнішній вплив (зовнішні причини) можна кваліфікувати як умови. У даному ж випадку місце здійснення туристсько-спортивних заходів відображає топологічну прив'язку самої системи спортивного туризму до конкретної ділянки поверхні планети (геоторіi), характеризуючи i 
Фактори формування попиту на спортивний туризм у світі (складено за матеріалами Л.Ю. Мажар [4])

\begin{tabular}{|c|c|c|}
\hline № & Групи факторів & Приклади факторів \\
\hline 1. & $\begin{array}{c}\text { Геоторіальні фактори } \\
\text { (фактори місця розташування) }\end{array}$ & $\begin{array}{c}\text { Просторове розташування туристсько-спортивних об’єктів, положення } \\
\text { об’єктів в системі географічних координат, топологічні характеристики } \\
\text { території, можливість прокладання туристсько-спортивних маршрутів, } \\
\text { геоситуаційні фактори тощо }\end{array}$ \\
\hline 2. & $\begin{array}{c}\text { Туристсько-рекреаційні } \\
\text { потреби людини }\end{array}$ & $\begin{array}{c}\text { Вибір місця подорожі та виду туристсько-спортивної діяльності в } \\
\text { залежності від своїх уподобань, рівня культури, рівня туристсько- } \\
\text { спортивної майстерності тощо }\end{array}$ \\
\hline 3. & Природно-рекреаційні фактори & $\begin{array}{c}\text { Наявність туристсько-спортивних об’єктів певного виду спортивного } \\
\text { туризму, різноманітність природних туристсько-спортивних перешкод, } \\
\text { наявність атрактивних об’єктів тощо }\end{array}$ \\
\hline 4. & Історико-культурні чинники & Наявність історико-культурних пам'яток \\
\hline 5. & Економічні фактори & $\begin{array}{c}\text { Рівень життя населення в країнах і регіонах, що генерують турпотоки, } \\
\text { матеріальні можливості здійснення туристсько-спортивної подорожі } \\
\text { тощо }\end{array}$ \\
\hline 6. & Геополітичні фактори & $\begin{array}{c}\text { Стабільність геополітичної ситуації в регіоні, відсутність загрози } \\
\text { військових конфліктів, терористичних актів, особистої безпеки, } \\
\text { сприятлива криміногенна ситуація тощо }\end{array}$ \\
\hline 7. & $\begin{array}{c}\text { Організаційно-управлінські } \\
\text { фактори }\end{array}$ & $\begin{array}{c}\text { Адміністративно-правове забезпечення туристсько-спортивної } \\
\text { діяльності, наявність управлінських структур національного та } \\
\text { регіонального рівня у відповідних органах влади, інформаційних центрів, } \\
\text { наявність підрозділів контрольно-рятувальної служби в районі тощо }\end{array}$ \\
\hline 8. & Інфраструктурні фактори & $\begin{array}{c}\text { Наявність інфраструктурних об'єктів, що забезпечують роботу всієї } \\
\text { туристсько-спортивної системи: транспортні шляхи і засоби, засоби } \\
\text { комунікації, інформаційне забезпечення тощо }\end{array}$ \\
\hline 9. & Матеріально-побутові фактори & $\begin{array}{c}\text { Наявність матеріально-технічної бази для забезпечення проживання та } \\
\text { харчування туристів, засоби розміщення, об’єкти харчування, об’єкти } \\
\text { для організації активного дозвілля та розваг, санітарно-гігієнічне } \\
\text { облаштування об’єктів тощо }\end{array}$ \\
\hline 10. & $\begin{array}{c}\text { Соціально-психологічні } \\
\text { чинники }\end{array}$ & $\begin{array}{c}\text { Формування позитивного образу туристського регіону, створення } \\
\text { сприятливої громадської думки, створення психологічного комфорту } \\
\text { в спілкуванні з місцевим населенням, психологічна сумісність і } \\
\text { комфортність туристів тощо }\end{array}$ \\
\hline 11. & Екологічні фактори & $\begin{array}{c}\text { Екологічна ємність туристсько-спортивної дестинації, екологічні ризики } \\
\text { в рамках туристсько-спортивної дестинації, фізіологічна комфортність } \\
\text { території, рівень техногенного забруднення території та антропогенного } \\
\text { забруднення ландшафтів тощо }\end{array}$ \\
\hline 12. & Медико-санітарні фактори & $\begin{array}{c}\text { Епідеміологічна ситуація в рамках туристсько-спортивної дестинації, } \\
\text { необхідність щеплень та профілактичних заходів, загроза загострення } \\
\text { хронічних захворювань у період перебування в туристсько-спортивній } \\
\text { дестинації, якість продуктів харчування та питної води, якість медичного } \\
\text { обслуговування, гарантії дотримання медичного страхування тощо }\end{array}$ \\
\hline 13. & Рекреаційно-діяльнісні фактори & $\begin{array}{c}\text { Створення тематичних парків, парків розваг, анімаційних майданчиків, } \\
\text { спортивних комплексів, гірськолижних трас, можливості для реалізації } \\
\text { різноманітних туристсько-спортивних програм, організація спортивних } \\
\text { заходів тощо }\end{array}$ \\
\hline 14. & Інноваційні фактори & $\begin{array}{l}\text { Можливості використання новітніх технологій в спортивному туризмі } \\
\text { (JPS-навігація, мобільний зв'язок), реалізація передумов для розвитку } \\
\text { інноваційних видів туризму тощо }\end{array}$ \\
\hline 15 . & $\begin{array}{c}\text { Фактори кадрового } \\
\text { забезпечення }\end{array}$ & $\begin{array}{c}\text { Наявність підготовлених кадрів гідів-провідників, рятувальників, } \\
\text { носильників (шерпів), створення системи підготовки та перепідготовки } \\
\text { кадрів та підвищення кваліфікації працівників сфери туризму тощо }\end{array}$ \\
\hline
\end{tabular}


геоторіальну унікальність. Саме властивості території, пов'язані 3 місцем розташування специфічних спортивних рекреаційно-туристських ресурсів, визначають конкретну геоситуацію і вплив «місця» на особливості формування i розвитку системи спортивного туризму.

Специфічні у спортивному туризмі туристськорекреаційні потреби в різних своїх проявах визначає цільове призначення туристсько-спортивної діяльності. Головний сенс потреб полягає в тому, що вони виступають як спонукання до дії. Незаперечним фактом $є$ те, що потреби можуть бути реалізовані тільки через фізичну або розумову діяльність, тому вони і $€$ найпотужнішими за своєю силою чинниками формування та розвитку відповідних суспільних систем, які виступають у якості механізму досягнення мети.

До числа рекреаційних потреб можна віднести вибір місця подорожі та виду туристсько-спортивної діяльності в залежності від своїх уподобань, рівня культури, рівня туристсько-спортивної майстерності, потреби в задоволенні цікавості, прагнення до різноманітності знань, емоцій, вражень, самоствердження тощо. Історично такі потреби змінюються у зв'язку з еволюцією суспільства, і в даний час виділяють три великі групи рекреаційних потреб, орієнтованих на відновлення фізичних $\mathrm{i}$ духовних сил, розвиток фізичних i духовних сил людини i формування нових рис i якостей особистості, нового способу життя тощо. У свою чергу, формування потреб залежить від багатьох умов, пов'язаних 3 життям потенційних туристів (матеріальне благополуччя, мода, вплив реклами тощо).

Однією 3 проблем вивчення туристськоспортивних потреб $\epsilon$ просторовий «розрив» між територією формування потреб у місці постійного проживання і територією реалізації цих потреб. На наш погляд, потреба стає фактором по відношенню до конкретної дестинації в той момент, коли турист прибуває разом зі своїми потребами саме в цю туристсько-спортивну дестинацію.

Можна припустити, що туристсько-спортивні потреби - це багатостадійне явище. Можна виділити чотири стадії формування цих потреб:

- потенційну - формування потреб, їх усвідомлення, прийняття рішень про методи та способи реалізації в подальшому;

- організаційну - оформлення документів 3 організації туристської подорожі, придбання квитків, придбання туристського спорядження, необхідного інвентарю, продуктів харчування тощо;

- стадію реалізації - безпосереднє задоволення туристсько-спортивних потреб в рамках конкретної подорожі;

- пострекреаційну стадію - повернення 3 туристської подорожі, оцінка ступеня відповідності потреб рівню їх реалізації та задоволеності подорожжю в цілому, коректування туристськоспортивних потреб і можливостей їх реалізації.

Природно-рекреаційні фактори включають всі властивості природних об'єктів і явищ, які безпосередньо використовуються в туристськоспортивній діяльності на даному етапі розвитку активного туризму (природні рекреаційні об'єкти, природні перешкоди різних видів спортивного туризму), естетичні властивості ландшафту, пам'ятки природи, атрактивні об'єкти тощо. Всі ці фактори відображають можливості території у формуванні природно-рекреаційної підсистеми спортивного туризму і їі просторових параметрів.

Історико-культурні чинники мають додатковий, опосередкований вплив у спортивному туризмі. Вони дуже багатогранні і «багатошарові». У матеріальній і духовній складових спостерігається, як правило, «нашарування» різночасових об'єктів: історико-культурна спадщина як свідчення різних епох, пам'ятники зодчества та монументального мистецтва, культові споруди, сучасна архітектура, духовна культура і традиції минулих часів, сучасне мистецтво тощо.

Економічні фактори формування попиту на спортивний туризм мають особливе значення в умовах ринкової економіки. Формування системи спортивного туризму у відповідь на відповідні потреби повинно мати крім соціального ще i економічний ефект, тобто бути справою прибутковою і сприяти економічному розвитку регіону. Як і багато інших, економічні фактори проявляються у рівні життя населення в країнах і регіонах, що генерують туристсько-спортивні потоки, матеріальних можливостях туристів щодо здійснення туристськоспортивної подорожі в ту чи іншу туристськоспортивну дестинацію тощо.

Геополітичні фактори безпосередньо пов'язані iз забезпеченням безпеки туристів i враховують стабільність геополітичної ситуації в регіоні, наявність загрози військових конфліктів і терористичних актів, а також криміногенну ситуацію. Часто саме ці фактори є лімітуючими для розвитку туристсько-рекреаційної діяльності в деяких регіонах світу (Близький Схід, Центральна i Південна Азія, Крим тощо).

\section{Організаційно-управлінські}

фактори відіграють важливу роль у безпосередньому забезпеченні роботи системи спортивного туризму на конкретній території. У багатьох країнах світу на національному рівні прийняті закони про туризм, працюють туристські адміністрації. В популярних туристсько-спортивних регіонах світу функціонують інформаційні центри, підрозділи державних контрольно-рятувальних служб, створені туристсько-спортивні асоціації, реалізується національна політика в сфері туризму, в тому числі спрямована на просування на світовому туристському ринку національного турпродукту.

Інфраструктурні фактори представляють наявність інфраструктурних об'єктів, що забезпечують роботу всієї туристсько-спортивної системи: транспортні шляхи i засоби, засоби комунікації, інформаційне забезпечення тощо. Туристсько-спортивні дестинації, як правило, $€$ важкодоступними 3 точки зору транспортних комунікацій, тому доправлення туристів до місць 
здійснення походів є важливим фактором.

Матеріально-побутові фактори пов'язані 3 організацією проживання (кемпінгові містечка, обладнані туристські стоянки), харчування та обслуговування туристів в місцях відпочинку, наявність об'єктів для організації активного дозвілля та розваг, санітарно-гігієнічне облаштування об'єктів тощо. Це важлива група чинників, хоча ii можна розглядати і в складі інфраструктурних факторів.

Соціально-психологічні

чинники, проявляються подвійно через властивості самого спортивного туризму і через туристів-спортсменів, впливаючи на формування та реалізацію специфічних туристсько-спортивних потреб. До останніх можна віднести наявність рекреаційного часу, соціальний статус, схильність до впливу інформаційно-рекламної пропаганди, соціальнопсихологічні властивості особистості туриста (етнічна і конфесійна самосвідомість і їх прояви в період відпочинку, комунікативні властивості особистості, рівень культури, темперамент, характер тощо). Важливим є формування позитивного образу туристського регіону, створення сприятливої громадської думки, створення психологічного комфорту в спілкуванні 3 місцевим населенням, психологічна сумісність i комфортність самих туристів тощо.

Екологічні фактори у багатьох випадках обмежують туристсько-спортивну діяльність в рамках конкретних територій, i пов'язано це, в першу чергу, 3 екологічною ємністю природнорекреаційних підсистем, екологічними ризиками. Крім того, розвитку туризму на багатьох територіях перешкоджає високий рівень техногенного забруднення, антропогенного забруднення ландшафтів, в тому числі радіаційного.

Медико-санітарні фактори, що впливають на здоров'я туристів, надають пряму дію на функціонування системи спортивного туризму. Несприятлива епідеміологічна ситуація в певних регіонах, необхідність профілактичних щеплень та профілактичних заходів, загроза загострення хронічних захворювань стримують потік туристів до місць поширення кліщового енцефаліту, малярії, лихоманки Ебола та інших захворювань. Важливим $€$ якість продуктів харчування та питної води, якість медичного обслуговування, гарантії дотримання медичного страхування в районах подорожей тощо.

Рекреаційно-діяльнісні фактори виділені в окрему групу саме тому, що перебування туристів у місцях відпочинку пов'язано, як правило, з певними видами діяльності, які вимагають створення особливих об'єктів-тематичних парків, парків розваг, анімаційних майданчиків, спортивних комплексів, гірськолижних трас тощо. Вони створюють можливості для реалізації різноманітних туристськоспортивних програм, організації спортивних заходів тощо.

Інноваційні фактори, пов'язані з впровадженням новітніх технологій у сферу рекреації і туризму, 3 кожним роком роблять все більший вплив на iii розвиток. Сюди можна віднести можливості використання новітніх технологій в спортивному туризмі (JPS-навігація, мобільний зв’язок), реалізація передумов для розвитку інноваційних видів туризму впровадження нових видів активного туризму та дозвілля (джампінг, польоти на повітряній кулі, дайвінг тощо).

Група факторів кадрового забезпечення стає все більш значущою у зв'язку зі збільшенням числа туристських прибуттів і збільшеним рівнем вимог до якості та безпеки туристсько-спортивного обслуговування. У кожній країні, залученої в міжнародну туристську діяльність, склалася своя національна система підготовки кадрів, система підготовки кваліфікованих рятувальників, система фахового супроводу туристів для сфери туризму взагалі та спортивного туризму зокрема.

Висновки. Таким чином, вивчення факторів як основних рушійних сил формування та розвитку туризму взагалі та спортивного туризму зокрема $\epsilon$ однією з ключових проблем, яка не втрачає своєї актуальності з плином часу.

Отже, всі процеси, що зумовлюють формування попиту на спортивний туризм у світі, визначаються дією причин, які можна поділити на більш суттєві внутрішні причини, що діють в рамках самої системи спортивного туризму і визначають іiі структуру та основні властивості, і зовнішні причини, пов'язані 3 властивостями оточуючого середовища. При цьому внутрішні причини можна кваліфікувати як «фактори», а зовнішні причини як «умови». Розмежування системи спортивного туризму i оточуючого її середовища носить умовний характер, при цьому з розвитком самого спортивного туризму розширюються просторові i структурні рамки системи.

Особливе значення для формування попиту на спортивний туризм у світі мають умови, пов'язані 3 географічним положенням, одним з різновидів якого $є$ туристсько-географічне положення, яке характеризує становище досліджуваної системи по відношенню до об’єктів туристсько-рекреаційної діяльності. Фактори як рушійні сили, що визначають формування та розвиток попиту на спортивний туризм у світі, $є$ внутрішніми причинами, пов'язаними, насамперед, 3 властивостями самої системи. Спортивний туризм як відкрита інтерактивна система схильна до впливу ззовні, тому через вплив (свідомий чи стихійний) на ті чи інші фактори можна сприяти цілеспрямованому розвитку системи спортивного туризму в світі.

\section{References:}

1. Kolotuha O. V. Sportivnij turizm: spìvvìdnošennâ ponât' [Sports tourism: the relationship between the concepts]. Geografîa ta turizm [Geography and tourism], 2013, Vol. 26, pp. 3-13. (In Ukrainian). 
2. Kolotukha O. Sports tourism as territorial social geographical system. European science review, 2014, Vol. 1 (January-February), pp. 123-134.

3. Lefebvre H. The Production of Space. Oxford UK \& Malden USA: Blackwell, 2007, 454 p.

4. Mažar L. U. Teoretičeskie osnovy analiza uslovij i faktorov formirovaniâ territorial'nyh turistskorekreacionnyh sistem [Theoretical framework for the analysis of conditions and factors determining formation of the territorial tourism-recreational systems]. Smolensk, 2008, 15 p. (In Russian).

5. Mironenko N. S., Tverdohlebov I. T. Rekreacionnaâ geografiâ [Recreational geography]. Moscow, 1981, 207 p. (In Russian).

6. Preobraženskij V. S., Vedenin U. A., Zorin I. V., Muhina L. I. Territorial'naâ rekreacionnaâ sistema kak ob'ekt izučeniâ geografičeskih nauk [Territorial recreational system as an object of geographical study]. Izvestiâ AN SSSR. Seriâ geografičeskaâ [Proceedings of the Academy of Sciences of the USSR. Geographical series], 1974, Vol. 2, pp. 34-42. (In Russian).

7. Sovetskij ènciklopedičeskij slovar' [Soviet encyclopedic dictionary]. Moscow, 1981, $1600 \mathrm{p}$.

8. Teoretičeskie osnovy rekreacionnoj geografii [Theoretical foundations of recreational geography]. Moscow, 1975, 224 p. (In Russian). 